\title{
Tetremeles Nudiflora Leaves Extract as Green Corrosion Inhibitor for Mild Steel in Hydrochloric Acid Solution
}

\author{
K. Vishalakshi ${ }^{1}$, P. R. Sivakumar ${ }^{1}$ and A. P. Srikanth ${ }^{1 *}$ \\ ${ }^{1, *}$ PG \& Research Department of Chemistry, Government Arts College (Autonomous), Coimbatore, TN, India.
}

\begin{abstract}
The efficiency of alcoholic extract of Tetrameles Nudiflora (TN) leaves as an environmentally friendly inhibitor for mild steel in $1 \mathrm{~N} \mathrm{HCl}$ solution has been investigated by weight loss method, potentiodynamic polarization measurements and electrochemical impedance spectroscopy techniques. Inhibition efficiency was found to be about $84.26 \%$ at $15 \mathrm{v} / \mathrm{v}$. Polarization curves revealed that TN leaves extract act as mixed type of inhibitor. Organic moieties present in the extract are found responsible for effective performance of the inhibitor which was well supported by FTIR studies. Corrosion current increases and inhibition efficiency decreases with temperature increasing in $\mathrm{HCl}$ solutions with and without Tetrameles Nudiflora leaves extract. The surface morphology analysis was confirmed by Scanning Electron Microscopy (SEM). Inhibition efficiencies obtained from electrochemical techniques and weight loss method are in good agreement.
\end{abstract}

Keywords: Corrosion inhibition, Polarization techniques, Scanning Electron Microscope, Weight loss method.

\section{Introduction}

The study of mild steel corrosion is theoretical and practical importance [1]. Acid solutions are widely used for the removal of rust and scale in several industrial processes such as pickling, chemical and electrochemical etching, industrial acid cleaning, cleaning of oil refinery equipment, oil well acidizing and acid descaling, resulting in huge economic losses and many potential safety questions due to metallic corrosion [211]. Corrosion inhibitor of organic matter is preferred because it has relatively high affinity to the metal, its value of high efficiency, and also eco-friendly. The effectiveness of organic compounds as inhibitor has been greatly influenced by the presence of hetero atoms $(\mathrm{O}, \mathrm{N}, \mathrm{P}$ and $\mathrm{S})$, polar groups, pi-bond, and the lone pair as it becomes a mean for inhibitors to do coordinated chemisorption/binding to the metal [12-17]. There has been extensive research done to develop inhibitors that are cost effective and environmentally friendly. Most of the inhibitors developed from natural sources such as plants are found to have the presence of heterocyclic compounds, nitrogen, Sulfur and oxygen atoms and these contribute greatly to inhibit ion of corrosion via various mechanisms [18-19]. Thus natural products (derived from plant materials) are being studied for their corrosion inhibition potential as they are showing good corrosion protection and are more environment friendly [20-21]. The goal of the present paper is to test the extract of Tetremeles Nudiflora leaves as an environmentally friendly inhibitor for the acid corrosion of mild steel, by various techniques such as weight loss method, polarization techniques and phytochemical studies.

\subsection{Preparation of mild steel specimen}

\section{Materials and Methods}

Mild steel strips were mechanically cut into strips of size $4 \mathrm{~cm} \times 2 \mathrm{~cm} \times 0.1 \mathrm{~cm}$ containing the composition of (C- $0.030 \%$, Mn- $0.169 \%$, Si- $0.015 \%$, P- $0.031 \%, \mathrm{~S}-0.029 \%$, Cr- $0.029 \%$, Ni- $0.030 \%$, $\mathrm{Mb}-0.016 \%$, and $\quad \mathrm{Cu}-0.017 \%$ ) and the remainder Fe and provided with a hole of uniform diameter to facilitate suspension of the strips in the test solution for weight loss method. For electrochemical studies, mild steel strips of the same composition but with an exposed area of $1 \mathrm{~cm}^{2}$ were used. Mild steel strips were polished by using emery paper of $(400,600,800,1000$, and 1200) grade, it was then dried and stored in a desiccator to avoid moisture before using it for corrosion studies. Accurate weight of the metal was taken using four digital electronic analytical balances (Shimadzu ay 220).

\subsection{Preparation of the plant extract}

The Tetrameles Nudiflora (TN) plant leaves were taken and cut into small pieces, and dried in room temperature and ground well in to powder. $20 \mathrm{~g}$ of the powder was refluxed in $200 \mathrm{ml}$ ethanol and it was kept overnight. The refluxed solution was filtered and the filtered liquor was evaporated to $250 \mathrm{ml}$ dark green residue and extracted with separating funnel. The solution was evaporated and the dark green solid residue obtained after complete drying was preserved in a desiccator. The residue so obtained was used in preparing different concentrations of the extracts in hydrochloric acid solution. The solution was expressed in $\mathrm{v} / \mathrm{v}$. 


\subsection{Weight loss method}

Mild steel specimens were immersed in $200 \mathrm{ml}$ of $1 \mathrm{~N} \mathrm{HCl}$ solution of various concentration of the inhibitor in the absence and presence of mild steel for 24 hours. The weights of the specimens before and after immersion containing were determined using four digit analytical balances (Shimadzu ay 220).

From the mass loss measurements, the corrosion rate was calculated using the following relationship.

$$
\mathrm{CR}(\text { mmpy })=\frac{\mathrm{K} \times \text { Weight Loss }}{\mathrm{D} \times \mathrm{A} \times \mathrm{t}(\text { in hours })}
$$

Where, $\mathrm{K}=8.76 \times 10^{4}$ (constant), $\mathrm{D}$ is density in $\mathrm{gm} / \mathrm{cm}^{3}(7.86), \mathrm{W}$ is weight loss in grams and $\mathrm{A}$ is area in $\mathrm{cm}^{2}$. The inhibition efficiency (\%) was calculated using equation (2) respectively,

$$
\text { IE }(\%)=\frac{W_{0}-W_{i}}{W_{0}} \times 100
$$

Where, $\mathrm{W}_{0}$ and $\mathrm{W}_{\mathrm{i}}$ are the weight loss in the absence and presence of the inhibitor.

\subsection{FTIR measurements}

FTIR spectra were recorded in a Bruker ALPHA 8400S spectrophotometer. The film was carefully removed, mixed thoroughly with $\mathrm{KBr}$ made in to pellets and FTIR spectra were recorded.

\subsection{Potentiodynamic polarization methods}

Potentiodynamic polarization measurements were carried out using IVIUM electrochemical analyzer. The polarization measurements were made to evaluate the corrosion current, corrosion potential, and Tafel slope. Experiments were carried out in a conventional three electrode cell assembly with mild steel specimen of $1 \mathrm{~cm}^{2}$ as working electrode. Platinum electrode was used as counter electrode and calomel electrode was used as reference electrode. A time interval of 15 minutes was given for each experiment to attain the steady state open circuit potential (OCP). The polarization was carried from a cathodic potential of $-800 \mathrm{mV}$ (vs. SCE) to an anodic potential of $-200 \mathrm{mV}$ (vs. SCE) at a sweep rate of $1 \mathrm{mV}$ per second. The inhibitor efficiency was calculated using the formula:

$$
\text { IE }(\%)=\frac{\mathrm{I}_{\text {Corr }}-\mathrm{I}_{\text {Corr }}^{*}}{\mathrm{I}_{\text {Corr }}} \times 100
$$

Where $\mathrm{I}_{\text {corr }}$ and $\mathrm{I}_{\text {corr }}$ are corrosion current in the absence and presence of inhibitors.

\subsection{Electrochemical impedance method}

The electrochemical AC- impedance experiments were carried out in a conventional three electrode cell assembly as that used for potentiodynamic polarization studies. A sine wave with amplitude of $10 \mathrm{mV}$ was superimposed on the steady state open circuit potential. The real part (Z') and the imaginary part (Z') were measured at various frequencies in the range of $100 \mathrm{KHz}$ to $10 \mathrm{MHz}$. A plot of Z' versus Z' was made. From the plot, the charge transfer resistance $\left(\mathrm{R}_{\mathrm{ct}}\right)$ was calculated, and the double layer capacitance $\left(\mathrm{C}_{\mathrm{dl}}\right)$ was then calculated using formula:

$$
\mathrm{C}_{\mathrm{dl}}=\frac{1}{2 \pi} \mathrm{f}_{\max } \mathrm{R}_{\mathrm{ct}}
$$

Where $R_{c t}$ is charge transfer resistance, and $C_{d l}$ is double layer capacitance. The experiments were carried out in the absence and presence of different concentration of inhibitor.

$$
\mathrm{IE} \%=\frac{\mathrm{R}_{\mathrm{ct}}-\mathrm{R}_{\mathrm{ct}}^{0}}{\mathrm{R}_{\mathrm{ct}}} \times 100
$$

Where $\mathrm{R}_{\mathrm{ct}}$ and $\mathrm{R}_{\mathrm{ct}}^{0}$ are the charge resistance values in the inhibited and uninhibited solution respectively.

\subsection{Phytochemical analysis}

Phytochemical screening were performed to assess the qualitative chemical composition of the different samples of plants extract using commonly employed precipitation and coloration reactions to identify the major secondary metabolites like alkaloids, flavonoids, glycosides, proteins, phenolic compounds, saponins, starch, steroids, tannins and terpenoids.

\subsection{Scanning electron microscopy}

The mild steel specimen immersed in blank and in the inhibitor solution for a period of one day was removed, rinsed with double distilled water, dried and observed in a scanning electron microscope to examine the surface morphology. The surface morphology measurements of mild steel were examined using (JEOL) computer controlled scanning electron microscope. 


\subsection{Weight loss method}

\section{Results and Discussion}

Weight loss studies were carried out at four different concentrations ranging from 5-20 v/v and the inhibition efficiency (IE \%) values calculated are presented in Table 1. From the table, it is noted that the IE increases with increasing concentration of the inhibitor. The extract showed the maximum inhibition efficiency of $84.26 \%$ in hydrochloric acid at the optimum concentration of $15 \mathrm{v} / \mathrm{v}$. This result indicated that TN Plant leaves extract could act as an excellent corrosion inhibitor.

TABLE 1. Data from Weight Loss Method for Mild steel corrosion in $1 \mathrm{~N} \mathrm{HCl}$ solutions at various concentrations of TN leaves extract

\begin{tabular}{|l|l|l|}
\hline Conc. of TN leaves extract (v/v) & Corrosion rate (mmpy) & Inhibition Efficiency $(\%)$ \\
\hline Blank & 0.0198 & $*$ \\
\hline 5 & 0.0054 & 72.51 \\
\hline 10 & 0.0040 & 79.66 \\
\hline 15 & 0.0031 & 84.26 \\
\hline 20 & 0.0036 & 81.65 \\
\hline
\end{tabular}

\subsection{FT-IR measurement}

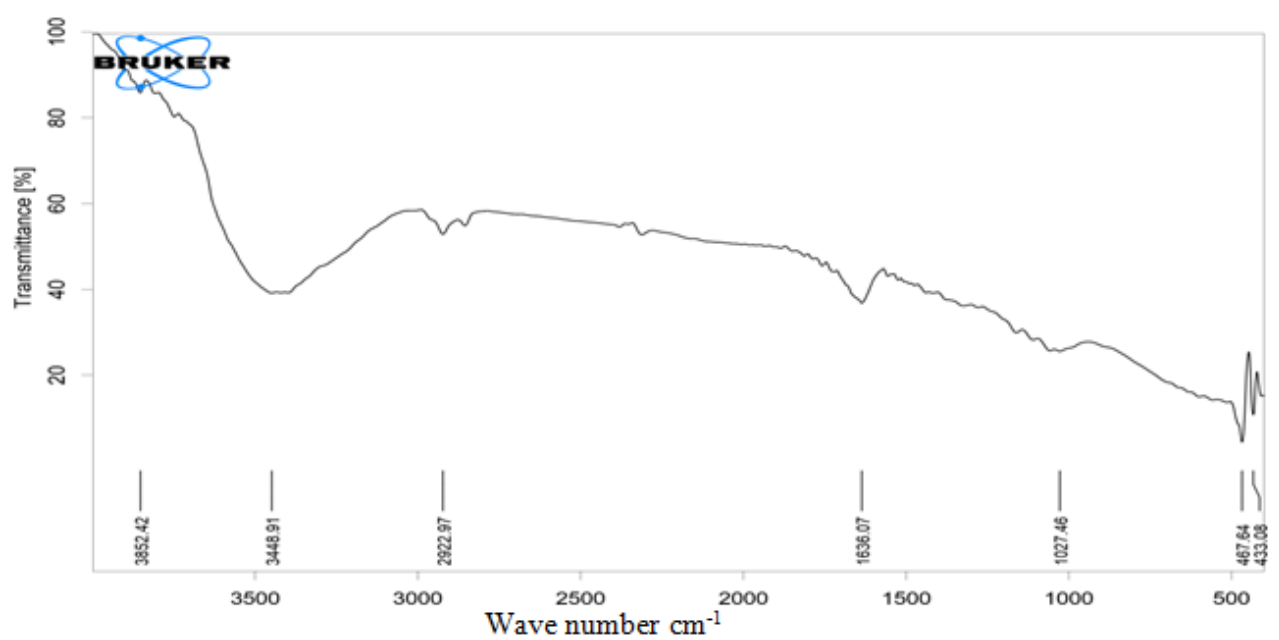

Figure 1: FTIR Spectrum of Tetrameles Nudiflora (TN) leaves extract

The chemical constituents that contribute to the corrosion inhibition have specific functional groups. The inhibitors samples were analysed with FTIR to identify the functional groups present in the extracts. TN leaves extract showed strong and sharp absorption peak at $3448 \mathrm{~cm}^{-1}$, which indicates the presence of hydroxyl group. The strong stretching vibration was observed at $2922 \mathrm{~cm}^{-1}$ indicates the presence of $\mathrm{CH}_{3}$ (or) $\mathrm{N}-\mathrm{H}$ group. The peak occurs at the range of $1636 \mathrm{~cm}^{-1}$ indicated the presence of $\mathrm{C}=\mathrm{O}$ group. The absorption peak at $1027 \mathrm{~cm}^{-1}$ indicates the presence of $\mathrm{C}-\mathrm{O}$ group. From the FTIR spectrum, the TN leaves extracts may be containing the desirable chemical constituents that are common in good green inhibitors.

\subsection{Potentiodynamic polarization studies}

A

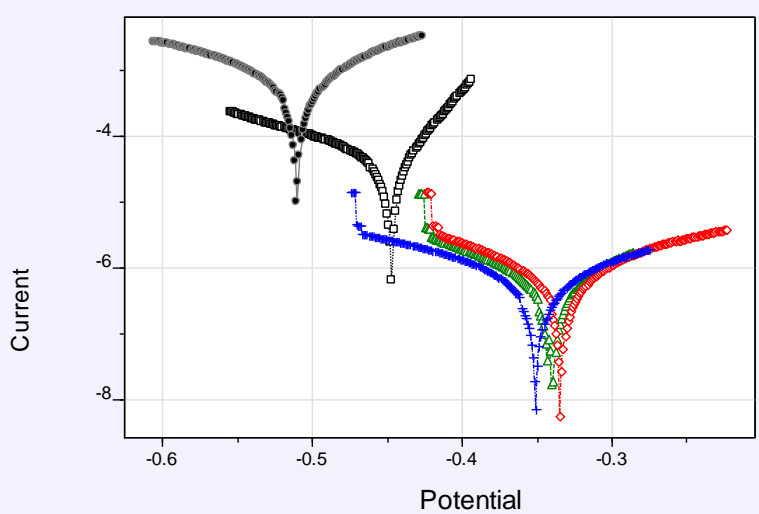

+ BLANK

$\diamond 5 \mathrm{v} / \mathrm{v}$

$\circ 10 \mathrm{v} / \mathrm{v}$

$\square 15 \mathrm{v} / \mathrm{v}$

\ $20 \mathrm{v} / \mathrm{v}$

Figure. 2

Tafel plots without and with different concentrations of TN leaves extract in $1 \mathrm{~N} \mathrm{HCl}$. 
The potentiodynamic polarization data are plotted in Fig. 2 as the Tafel plots for mild steel in $1 \mathrm{~N} \mathrm{HCl}$ with the addition of different concentrations of the plant extract. The corrosion kinetic parameters, such as corrosion potential $\left(\mathrm{E}_{\text {corr }}\right)$, corrosion current $\left(\mathrm{I}_{\mathrm{corr}}\right)$, anodic Tafel slope $\left(\mathrm{b}_{\mathrm{a}}\right)$ and cathodic Tafel slopes $\left(\mathrm{b}_{\mathrm{c}}\right)$, were derived from these curves are given in Table 2. It was observed from the table the $\mathrm{I}_{\text {corr }}$ values were progressively decreased with the steady increase in the concentration of the leaves extract. The maximum inhibition efficiency of $92.77 \%$ was obtained at $15 \mathrm{v} / \mathrm{v}$, was considered as the optimum concentration of the inhibitor. When compared with the blank $1 \mathrm{~N} \mathrm{HCl}$, the TN leaves extract showed a mixed mode of inhibition. Moreover in the presence of inhibitor system, the corrosion current decreased from 0.695 to $0.0502 \mu \mathrm{A} / \mathrm{cm}^{2}$. These observations confirmed the decrease in the oxidation of the metal and the formation of protective film on the metal surface [22].

Table 2. Potentiodynamic polarization parameters obtained from Tafel plots for the corrosion of mild steel in $1 \mathrm{~N} \mathrm{HCl}$ with various concentrations of TN leaves extract.

\begin{tabular}{|l|l|l|l|l|l|l|}
\hline $\begin{array}{l}\text { Conc. of TN } \\
\text { leaves (v/v) }\end{array}$ & $\begin{array}{l}\mathbf{E}_{\text {corr }} \mathbf{( m V )} \\
\text { vs. SCE }\end{array}$ & $\begin{array}{l}\mathbf{I}_{\text {corr }} \\
\left(\boldsymbol{\mu A} / \mathbf{c m}^{2}\right)\end{array}$ & $\begin{array}{l}\mathbf{C R} \\
(\mathbf{m m p y})\end{array}$ & $\begin{array}{l}\mathbf{b}_{\mathbf{c}} \\
(\mathbf{m V} / \mathbf{d e c})\end{array}$ & $\begin{array}{l}\mathbf{b}_{\mathbf{a}} \\
(\mathbf{m V} / \mathbf{d e c})\end{array}$ & $\begin{array}{l}\mathbf{I E} \\
(\boldsymbol{\%})\end{array}$ \\
\hline 0 & -0.5046 & 0.695 & 2.273 & 0.128 & 0.087 & - \\
\hline 5 & -0.3357 & 0.0677 & 0.0022 & 0.154 & 0.091 & 90.25 \\
\hline 10 & -0.3378 & 0.0610 & 0.0026 & 0.105 & 0.130 & 91.22 \\
\hline 15 & -0.3300 & 0.0502 & 0.1641 & 0.148 & 0.036 & 92.77 \\
\hline 20 & -0.4391 & 0.0551 & 0.0018 & 0.105 & 0.063 & 92.07 \\
\hline
\end{tabular}

\subsection{Electrochemical impedance studies}
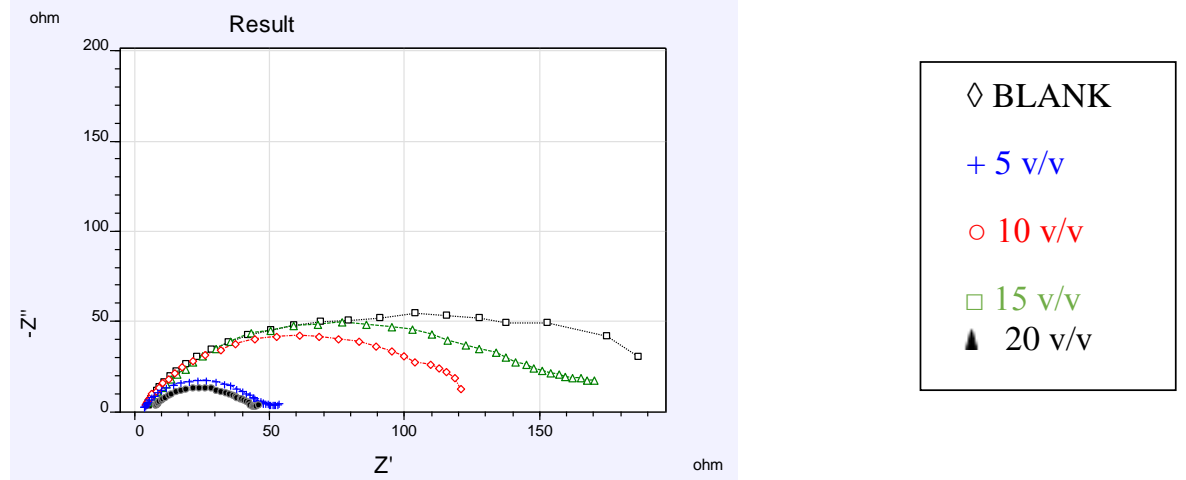

Figure 3: Nyquist plots for mild steel in $1 \mathrm{~N} \mathrm{HCl}$ acid solution without and with various concentration of $\mathrm{TN}$ leaves extract.

The corrosion behavior of mild steel in $1 \mathrm{~N} \mathrm{HCl}$ in absence and presence of $\mathrm{TN}$ leaves extract were investigated by EIS. Nyquist plots for mild steel in uninhibited and inhibited acid solutions containing different concentrations of TN leaves extract are shown in Fig 3 and data are given in Table 3. The impedance spectra showed a single semicircle and as the concentration of inhibitor increases diameter of the semicircle increases. It is evident from the results that TN leaves extracts inhibited the corrosion of mild steel in $1 \mathrm{~N}$ hydrochloric acid at all the concentrations used, and the inhibition efficiency increased continuously with increasing concentration.

The AC impedance of the inhibited system amplified with the inhibitor the $C_{\mathrm{dl}}$ values decreased with inhibitor. This decrease in $\mathrm{C}_{\mathrm{dl}}$ results from a decrease in local dielectric constant and / or an increase in the thickness of the double layer, suggested that inhibitor molecules inhibit the mild steel corrosion by adsorption at the metal / acid interface [23]. The depression in Nyquist semicircles is a feature for mild steel electrodes and often referred to as frequency dispersion and attributed to the roughness and other inhomogeneties of the mild steel [24]. The increase in $\mathrm{R}_{\mathrm{ct}}$ values is attributed to the formation of protective film at the metal solution interface [25-26]. These observations suggest that TN leaves extracts function by adsorption at the metal surface thereby causing decrease in $\mathrm{C}_{\mathrm{dl}}$ values and increase in $\mathrm{R}_{\mathrm{ct}}$ values.

Table 3. Electrochemical impedance parameters for mild steel in $1 \mathrm{~N} \mathrm{HCl}$ acid solution in the absence and presence of various concentration of inhibitor

\begin{tabular}{|c|c|c|c|c|c|}
\hline $\begin{array}{l}\text { Conc. of } T N \text { leaves } \\
\text { extract }(v / v)\end{array}$ & $\begin{array}{l}\text { Ret } \\
\left(\square \mathbf{c m}^{2}\right)\end{array}$ & $\begin{array}{l}\mathrm{Cdl} \\
\left(\mu \mathrm{F} \mathrm{cm} \mathrm{cm}^{-2}\right)\end{array}$ & $b_{c}(\mathrm{mV} /$ dec $)$ & $\begin{array}{l}\mathbf{b}_{\mathrm{a}} \\
(\mathrm{mV} / \mathrm{dec})\end{array}$ & $\begin{array}{l}\text { IE } \\
(\%)\end{array}$ \\
\hline 0 & 2.07 & $1.57 \times 10^{-5}$ & 0.128 & 0.087 & $*$ \\
\hline 5 & 2.56 & $1.97 \times 10^{-5}$ & 0.154 & 0.091 & 23.67 \\
\hline 10 & 3.09 & $0.80 \times 10^{-5}$ & 0.105 & 0.130 & 33.00 \\
\hline 15 & 3.38 & $1.06 \times 10^{-5}$ & 0.105 & 0.063 & 63.28 \\
\hline 20 & 4.03 & $0.67 \times 10^{-5}$ & 0.148 & 0.036 & 48.63 \\
\hline
\end{tabular}




\subsection{Phytochemical screening method}

Phytochemical screening of the aerial parts of plant's powder (alcoholic) extract was tested in order to find the presence of various chemical constituents included alkaloids, carbohydrates, proteins, saponins, triterpinoids and tannins, which are listed in Table 4.

Table. 4 Phytochemical screening test of TN leaves extract

\begin{tabular}{|l|l|l|}
\hline S.No & Phytochemical Test & Alcoholic extract of TN leaves \\
\hline 1 & Alkaloids & - \\
\hline 2 & Carbohydrates & + \\
\hline 3 & Proteins & - \\
\hline 4 & Glycoside & + \\
\hline 5 & Flavonoids & + \\
\hline 6 & Tannins & - \\
\hline 7 & Phenolic compounds & + \\
\hline
\end{tabular}

(+) is Present,

$(-)$ is absent

\subsection{Scanning electron microscopy (SEM)}

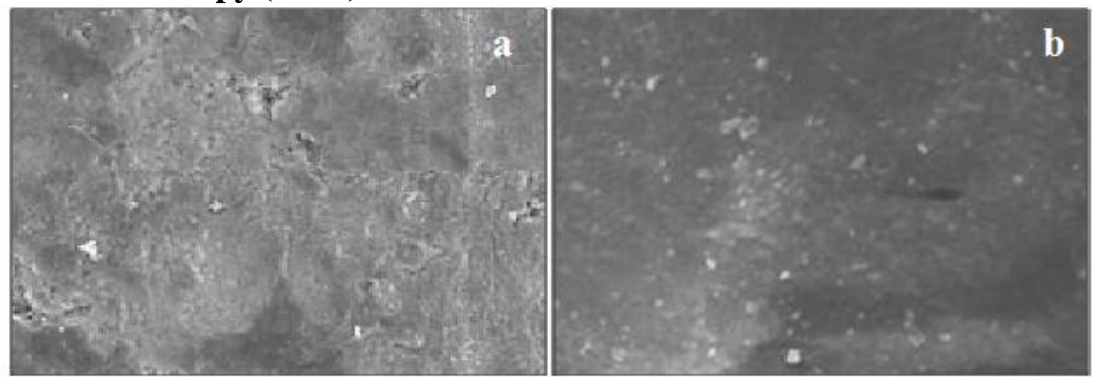

Figure. 4 SEM images of (a) Polished mild steel coupon without inhibitor and (b) mild steel coupon with inhibitor.

The surface morphology of the mild steel samples in $1 \mathrm{~N} \mathrm{HCl}$ in the absence and in presence of TN leaves extract are shown in Fig 4. The image (4a) shows badly damaged surface obtained when the metal was kept immersed in $1 \mathrm{~N} \mathrm{HCl}$ for $24 \mathrm{~h}$ without inhibitor indicates significant corrosion. However, in the presence of inhibitor (Fig. 4b), the surface has remarkedly improved with respect to its smoothness indicating considerable reduction of corrosion rate. This improvement in surface morphology is due to the formation of a good protective film of TN leaves extract on mild steel surface which is responsible for inhibition for corrosion.

\section{Conclusion}

Tetrameles Nudiflora leaves acts as efficient corrosion pickling inhibitor on mild steel in $1 \mathrm{~N} \mathrm{HCl}$ acid. The use of TN plants as corrosion inhibitor is environmentally safe, nontoxic, eco-friendly, cost effective and easily available. The TN leaves extracts showed maximum inhibition efficiency of $84.26 \%$ at the optimum concentration of $15 \mathrm{v} / \mathrm{v}$ for one day immersion time at room temperature. Results obtained in nonelectrochemical methods (weight loss method) have good agreement with the electrochemical methods. The TN leaves extracts act as a mixed type inhibitor on the metal surface. SEM examination showed that there was an improvement in the surface morphology of the as corroded inhibited mild steel compared to uninhibited samples. The results of the electrochemical tests and weight loss measurements are consistent and show that this green inhibitor, which was isolated from the ethanolic extract of TN leaves, can be potentially applied as an anticorrosive agent for mild steel in hydrochloric acid environment.

\section{References}

[1]. A . P. Srikanth, S. Nanjundan, and N. Rajendran, Prog. Org. Coat., 60, (2007), 320.

[2]. B. Obot, and N. O. Obi-Egbedi, Corros. Sci. 52, (2010), 198-204.

[3]. M.Yadav, D. Sharma, S. Kumar, I. Bahadur, and E. E. Ebenso, Int. J. Electrochem. Sci., 9, (2014), 6580-6593

[4]. M. Yadav, S. Kumar, I. Bahadur, and D. Ramjugernath, Int. J. Electrochem. Sci., 9, (2014), 3928-3950.

[5]. H. Vahisht, S. Kumar, I. Bahadur, G. Singh, Int. J. Electrochem. Sci., 8, (2013), 684-699.

[6]. M. Yadav, S. Kumar, I. Bahadur, D. Behera, and D. Ramjugernath, Int. J. Electrochem. Sci. 9, (2014), 5235-5257.

[7]. M. Yadav, R. R. Sinha, S. Kumar, I. Bahadur, and E. E. Ebenso, J. Mol. Liq., 208, (2015), 322-332.

[8]. H. Vahisht, I. Bahadur, S. Kumar, G. Singh, D. Ramjugernath, and E. E. Ebenso, Int. J. Electrochem. Sci. 9, (2014), 5204-5221.

[9]. M. Yadav, S. Kumar, I. Bahadur, D. Behera, D. Ramjugernath, Int. J. Electrochem. Sci., 9, (2014), 6529-6550.

[10]. M. Yadav, S. Kumar, I. Bahadur, D. Behera, and D. Ramjugernath, Int. J. Electrochem. Sci., 9, (2014), 602-624.

[11]. H. Vahisht, I. Bahadur, S. Kumar, G. Singh, D. Ramjugernath, and E. E. Ebenso, Int. J. Electrochem. Sci., 9, (2014), 2896-2911. 
[12]. Deng. Shuduan, Li. Xianghonh., Inhibition by Ginko leaves extract of the corrosion of steel in $\mathrm{HCl}_{\text {and }} \mathrm{H}_{2} \mathrm{SO}_{4}$ solutions, Corrosion Science, 55, (2011), 407-415.

[13]. F. S. De Souza. A. Spinelli. Caffeic acid as a green corrosion inhibitor for mild steel, Corrosion Science, 51, (2008), 642-649.

[14]. Ambrish Singh, Ishtiaque Ahamad, Quraishi. A. Mumtaz, Piper Longum extract as green corrosion inhibitor for aluminium in $\mathrm{NaOH}$ solution, Arabian Journal of Chemistry, (2012).

[15]. M. S. Al-Otaibi. A. M. Al-Mayouf, M. Khan, A. A. Mousa., S. A. Al-Mazroa, H. Z. Alkhathlan, Corrosion inhibitory action of some plant extracts on the corrosion of mild steel in acidic media, Arabian Journal of Chemistry, (2012).

[16]. A. Spinelli, F. S. De Souza Caffeic Acid as a green corrosion inhibitor for mild steel, Corrosion Science, 51, (2009), 642-649.

[17]. V. S. Sastri, Green Corrosion Inhibitors: Theory and Practice, $1^{\text {st }}$ Ed, Canada: John Wiley and Sons, Inc.

[18]. G. Gece, Corrosion Science, 50, (2008), 2981-2992.

[19]. R. A. Prabhu, T. V. Venkatesha, A. V. Shanbhag, G. M. Kulkarni, and R. G. Kalkhambkar, Corrosion Science, 50, (2008), 33563362.

[20]. M. Ramdani, H. Elmsellem, N. Elkhiati, , B. Haloui, A. Aouniti, M. Ramdani, Z. Ghazi, A. Chetouani, and B. Hammouti, Der Pharma Chemica, 7(2), (2015), 67-76.

[21]. F. Aouinti, H. Elmsellem, A. Bachiri, M-L. Facounnier, A. Chetouani, C. Belbachir, A. Aouniti, and B. Hammouti, Journal of Chemical and Pharmaceutical Research, 6(7), (2014), 10-23.

[22]. T. H. Ibrahim, and M. Abou Zour, Corrosion Inhibition of Mild Steel Using Fig Leaves Extract in Hydrochloric Acid Solution, Int. J. Electrochem. Sci., 6, 2011, p 6442-6455.

[23]. A. K. Singh, and M. A. Quraishi, Int. J. Electrochem. Sci. 7, (2012), 3222-3241.

[24]. H. Ashassi-Sorkhabi, D. Seifzadeh, and M. G. Hosseini, Corros Sci. 50, (2008), 3363-3370.

[25]. M. Lebrini, M. Traisnel, M. Lagrenee, B. Mernari, and F. Bentiss, Corros. Sci., 50, (2008), 473.

[26]. E. Mc. Cafferty, N. Hackerman, and S.Tsai, Corrosion, 38, (1982), 57. 